\title{
IMPACT OF POLITICALLY THEMED ADVERTISEMENT ON POLITICAL LITERACY: ROLE OF MEDIA PLANNING
}

\author{
SONAM MAHAJAN ${ }^{1} \&$ DR. ANSHU ARORA ${ }^{2}$ \\ ${ }^{I}$ Research Scholar, Amity School of Communication, AUUP \\ ${ }^{2}$ Associate Professor, Amity School of Communication, AUUP
}

\begin{abstract}
Television is one of the most influential mediums of communication. The advertisements on it play vital role in changing behavior of viewer through different techniques and patterns used in it to persuade the viewers. There are number of advertisements by different brands based on political and democratic issues.

The objectives of this study are -impact of Politics based advertisement of products on political literacy among viewers, impact of media planning of advertisement on political literacy, influence of Politics based advertisement of products on media planning, and mediating role of media planning between politically themed advertisement and political literacy.

Data is collected from 384 voters of Delhi-NCR through well designed questionnaire. Data Analysis is done with SPSS 21 and Amos 21.

The results revealed that there is significant positive and moderate influence of politics-based advertisement and media planning on political literacy and there is significant positive and moderate impact of politically themed advertisement on media planning. Also, there is partial mediation of media planning between politically themed advertisement and political literacy.

It is implicated that such advertisement should be promoted by channel partners, government and corporates for better awareness and participation of mass in democratic system.

KEYWORDS: Politics, Political Party, Politically Themed Advertisement, Media Planning, Political Literacy, and Democratic System
\end{abstract}

Received: Jun 10, 2020; Accepted: Jun 30, 2020; Published: Jul 22, 2020; Paper Id.: IJMPERDJUN2020423

\section{INTRODUCTION}

Television is one of the most influential mediums of communication (Kaur and Kaur, 2002). Television is an integral part of our life and the advertisements on it play vital role in changing behavior of viewer through different techniques and patterns used in it to persuade the viewers. This advertisement is not simply to the way the things are used by the consumers but also to change the perception of viewers towards the things being presented through advertisement.

Elections are very important for any democracy. It is exceptionally hard to contemplate how any voter cast vote in the favour of his or her choice for a party or a candidate. The Indian democracy makes it more troublesome in contrast with western governments. Many variables impact the choice of voter's in democracy like India, where numerous diversities impact the choice of voter's like cast, color, ideology, religion, region, family, identity and 
personality of candidates, parties, mass media and communications etc.

There are three types of advertisement to political literacy - one is by the political parties itself and other is by corporate based on political issues under social responsibilities, and third is by government itself. There are number of politically themed advertisement either creating awareness about our roles and responsibilities being effective citizen or based on political issue to awake the voters. The aim of this study is to study the impact of politically themed advertisement on stimulating voter's interest in political processes, agendas, issues and political ideology. The role of media planning is important in getting attention and having long lasting impression on viewers so impact of media planning on political literacy is planned in this study. Also, the mediating role of media planning between politically themed advertisement and political literacy of viewers.

\section{LITERATURE REVIEW}

Social advertising is the utilization of advertising to illuminate people in general about a social issue or to impact their conduct. It is intended to instruct or propel customers on a matter of social significance. Organizations utilize social advertising to improve organization's picture, notoriety and name mindfulness among the masses. Social advertising efforts are regularly fruitful in bringing issues to light. It is the application of commercial marketing ideas, learning, and procedures to non-commercial closures for the general public's welfare.During General Elections many organizations propelled social advertisement battles to advance races and voting. Brands took this occasion as the chance to end up noticeably a socially responsible organization by elevating and inspiring subjects to vote in favor of India.

Television can combine various image frameworks, for example, visual pictures, sounds, music, talked and composed dialect, and present them at the same time. Analysts have propelled two fundamental theories about the impacts of combining different image frameworks (Kozma, 1994). One probability is that the concurrent introduction of various image frameworks (sound and visual data) will compete for restricted cognitive assets and in this way may decrease viewers' comprehension and memory for the data exhibited. On the other hand, data displayed in various ways may cooperate to expand viewers' comprehension and memory. While it has been shown that multi-channel introductions require more attentional limit from the viewer than single channel introductions (Thorson, Reeves, and Schleuder, 1985). In support of this contention, there exist a few investigations that have inspected how sound (verbal portrayal) and visual (moving pictures) introductions of stories independently and combined influence youngsters' and adults' memory for the data displayed (Baggett and Ehrenfeucht, 1983; Beagles-Roos and Gat, 1983; Calvert, Huston, Watkins, and Wright, 1982; Hayes, Kelly, and Mandel, 1986; Neuman, 1989). According to Drew and Grimes (1987), the combination of repetitive sound and visual data is instructionally more viable in light of the fact that it enables the gathering of people to center thoughtfulness regarding the sound channel, where the most essential data is generally found, without diversion by conflicting data from the visual channel. Repetitive visual data has been appeared to help illuminate conceptual data exhibited on the sound channel (e.g., Calvert et al., 1982), and to disambiguate talked words (e.g., Baggett and Ehrenfeucht, 1983). Hanson (1989) has proposed that an alternate standard may apply for television programs in which the visual station is essential.It has been proposed (Kozma, 1994) that both the continuity and the pace of the data exhibited will influence comprehension and adapting, however there exists shockingly little research to bolster these cases. Program pace has been characterized as the measure of data exhibited per unit of time. In perspective of the absence of observational work around there, Kozma (1994) proposed a hypothetical model for how program pace may influence the watcher. It is revealed that comprehension and learning will be subject to whether the cognitive pace of the learner can stay 
aware of the program pace. Cognitive pace is characterized as the measure of data handled per unit of time. Data, in cognitive brain research, is measured as far as pieces (e.g., Miller, 1956), who's size relies on upon the nature and seriousness of the data. The pace of an introduction on television is normally not delicate to the cognitive pace of the watcher; it advances regardless of whether comprehension has been accomplished. Viewers, who know about the data introduced, might have the capacity to stay aware of the program design.

There exist a couple of concentrates that have inspected the adequacy of various types of content in instructional television and news programs. Of specific pertinence for the present reasons for existing are those examinations that are concerned with the effect of the association and introduction of data. Laurillard (1991) conducted a subjective report analyzing Open University understudies' understanding and misjudging of a television program that was a piece of their sociology course. It is found that viewers once in a while experience issues incorporating separate content arrangements into a composed entirety. In spite of the fact that these viewers may comprehend the content succession by arrangement, they experience issues coordinating them to determine primary focuses.

Some of the advertisements themed on political and democratic issues are mentioned below-

Pidilite Fevicol Television Commercial (TVC) was reflecting upon the current election environment in the nation. Fevicol has constantly centered their correspondence procedure around live circumstances, this TVC rides on the election fleeting trend. The TVC brings an interesting and comical go up against the race situation and in accordance with their prior promotions where the Fevicol mark utilized everyday circumstances entertainingly to convey. Fevicol Crazy Chairs TVC catches the climate made by the general get together races in the nation. It obtains the energy and enthusiasm of a typical man and along these lines making sync with the group of viewers.

Rupa Frontline intended to build voting rate has and advance the turnout in races propelled their TVC. The TVC was made by Scarecrow Communications and attempted to hit on the unconcerned approach towards voting which is an uncertain issue in India and the race measurements throughout the years demonstrate the same. Taking forward the previous slogan of Frontline - 'Sabse Aage' (Ahead of everybody), the new slogan - 'Rahoduniya se ekkadamaage' (Stay a stage in front of the world) makes the brand thought one stride further.

Hevells fans launched promotion campaign for bringing and acquiring change. A smart advert that plays on the brands, 'HawaaBadlegi' recommendation to convey the message that 'money for vote' trap won't work with the present upright electorate. The battle's message was clear and uproarious that pastors and civil servants are open hirelings and that is the thing that they ought to do.

Hindustan Unilever's (HUL), targeting urban first-time-voters launched their TVC on 'Voting as a coming-of-age moment'. The campaign is endorsed by the Election Commission. The campaign has been created by leading advertising professionals, Piyush Pandey and R Balakrishnan (Balki) chairman and chief creative officer with Lowe Lintas and Partners and top B-school students of the country. The campaign was born out of an initiative called Lessons in Marketing Excellence (L.I.M.E.), an inter b-school challenge conducted annually by HUL and CNBC TV18. With the elections around the corner, the four finalists were asked to come up with a plan to tackle voter apathy and ensure an increase in voter participation. The jury panel for the finale was chaired by the chief election commissioner V.S. Sampath. The winning case study, by students of Indian Institute of Management-Bangalore (IIM-B), highlighted the stark difference between how rural and urban citizens approach elections in a country with more than 800 million voters. Urban voters are 
more politically apathetic and therefore less likely to vote because they feel disconnected from the political candidates.

The Delhi-based Association for Democratic Reforms (ADR) came up with a commercial wherein Aamir Khan advising against selling of votes and going by the slogan, 'AchchekoChune, SachchekoChune' (Srinivasan, 2014).

Google India launched a campaign including 97-year old resigned teacher Shyam Saran Negi, India's first voter, from Kinnaur in Himachal Pradesh. The brief for O\&M Group Creative Director SukeshNayak was to converse with the great many first-time voters who are a piece of the Internet era. The point was to rouse them to vote of their own volition. Indeed, even a decision message from a brand will work just if the brand is in the thought set of the crowd the crusade is focusing on. As an Internet organization, which would see the young swing to it for explore on the surveys, from checking if names have been enlisted to the closest surveying corner, Google needed to be a piece of this critical stage in their lives (Sen, 2014).

ITC's Sunfeast Yippeecommercial was concocted for its gathering of people - children and moms both. A TVC, demonstrating a gathering of children going to frame their very own gathering with requests of getting rid of homework and so on diverted by the resemble noodles cooking adjacent, has been running on children's channels. The commercial does not straightforwardly discuss voting but rather without a doubt talks on making a gathering.

Tata Global Beverages Ltdlaunched an activity under their image Tata Tea, called 'Jaago Re'-Power of 49 campaigns, which was gone for ladies' voters. The target of the crusade was to make countless ladies' voters with a view that an educated female electorate would impel the political pioneers to incorporate ladies' issues in the in the expected races. There another TVC titled 'Kala Teeka' (Black speck), urges ladies to vote on the off chance that they need to bring a change (Srivastava, 2014).

The Idea Cellular Company highlighting the significance of versatile Internet to the masses propelled their new battle 'No ullubanoing'. What's more, one of the TVC indicates how a political pioneer is making enormous cases and one of the individuals from rally plays video on cell phone and says, 'pichle saal bhi yehi kaha tha, India ko no ullubanaoing'. Remembering the race stage going on, the promotion battle has thought of this decision themed notice, which beyond any doubt gels well with their belief system of 'No ullubanoing'. In spite of the fact that cell organizations have been giving Internet association with ages, it has still to be investigated by the vast mass of country territories. So, Idea's 'No ullubanoing' effort will undoubtedly interface with villagers. The conceptualization of the promotion film is finished by Lowe Lintas.

Hero Motocorp launched a crusade for its bicycle HF Deluxe, with a message for the Indian electorate, 'Abkibaar talent ko vote detehain'. The film highlights two men riding on a bicycle. Before they set off, the rider asks his companion who he will vote in favor of. He reacts that he will vote in favor of Ramesh, thinking: 'Hamaretarafkehain' (He is from our side/He is one of us). Enroute, they witness a cricket coordinate on a monster screen. At the point when made a request to stop, the rider tells his companion that he will when somebody from 'our side' is playing. The situation rehashes itself when they ride past a film star. As they see an ability indicate storing, the rider says Neha will win, since she is from their side. At the point when the baffled man reasons that there should be accentuation on ability, the rider makes his point: the races are India's greatest ability show, and one should vote in favor of the meriting. Saint needed to draw out a message amid the decision season through their HF Deluxe bicycle which has 'Naya Indian' as its gauge. We needed to focus on the adolescent of the nation who are getting more mindful and would be effectively voting this year. The TVC gives out the 
message that one ought not vote on the premise of standing, shading or ideology and take a gander at the master plan that is the manner by which the nation can advance.

WagonR, the compact car from the Maruti Suzuki stable, has confidence in the possibility that shorter crusades can bring the greatest changes. The brand's freshest battle was a 10-second TVC which offers a genuine conversation starter. Conceptualized by Dentsu Creative Impact, the battle tries to fortify WagonR as the brilliant decision. It utilizes the present most loved subject - General Elections - to drive its point to the masses. The TVC opens with a man hiding suspiciously alongside a stopped WagonR. At the point when the proprietor arrives, the man tries to give him a heap of money. He says to the proprietor, 'Take the cash and give me the auto'. The proprietor normally cannot. As the proprietor heads out in his WagonR, he asks watchers, 'On the off chance that you wouldn't offer your auto for some cash, why might you offer your nation out?' The TVC closes with a demand to all Indians to vote dependably. The thought behind the battle is to connect with the keen Indian voter (Sen, 2014).

Vicks Cough drops has discharged another battle that urges individuals to talk decisively. The legacy mark in their TVC advises its shoppers to talk their psyche decisively. 'Kehnemeinhichkich' (Hindi for dithering in talking) is the catchphrase of the present battle. In TVC, a young lady is ceased on the roadside by a government official's colleague who approaches her whom she voted in favor of. She tries to reply, yet can't do as such because of some bothering in her throat (an analogy for her faltering). In any case, in the wake of taking Vicks Coughdrops, she strikingly discloses to him that he will know the appropriate response when the outcomes are reported. The super toward the end states 'Jaisebhikhich, bolo binahichkich'(Menon, 2013).

ABP News channel's crusade made by Lowe Lintas 'how would you settle on your political choices?' intends to cut a space for itself with its decision related programming. The crusade's center idea is to urge individuals to settle on an educated decision about their competitor. The film opens to a gathering of companions having a happy talk on politics, particularly about the hopefuls and political gatherings challenging for the 2014 races. Some of them are attempting to make a genuine point, while the others removed the reality by making facetious comments. Towards the end, an ABP stay is included, inquiring as to whether this is the means by which they settle on their most imperative decision - that of who will lead the nation. The battle tries to get the watchers watch ABP News to shape the right political supposition. It abandons an intense message, 'sahirajneetikrai banana keliyedekhiyeesirf ABP News' (Nagpal, 2014).

Star Plus channel acquainted an activity with urge first time voters to enroll for the General Elections. The battle was driven by its famous face and youth symbol 'Veera'. In India, the quantity of potential first-time voters amid this race, is assessed at a huge 12 crores. In this light Star Plus, needed to spread mindfulness about voting rights among first time voters and activate the adolescent.

MTV India has launched a campaign to energize the young of the nation to vote. The battle called 'Shake the vote' is joined by a two-sided saying slogan, 'Dabaona... catch' and will look to activate all adolescents matured 18 and above to enlist themselves as voters. MTV has banded together with Rock the Vote (USA), a non-profit, non- divided association which pushes political mindfulness among youth crosswise over numerous nations including the USA, Canada and Chile. Established 21 years prior, Rock the Vote (USA) has enrolled more than 5 million youngsters to vote and has turned into a put stock in wellspring of data for youngsters about enlisting to vote and throwing a vote.

\section{METHODOLOGY}




\subsection{Research Objectives}

- To assess the impact of Politics themed advertisement of products on media planning for better effectiveness among viewers.

- To study the influence of media planning of advertisement on political literacy.

- To find the impact of politically themed advertisement on political literacy among viewers.

- To examine the mediating role of media planning between politically themed advertisement and political literacy.

\subsection{Proposed Alternate Hypotheses}

- $\mathrm{H}_{1}$ : There is significant and positive impact of politically themed advertisement on media planning in broadcasting for better effectiveness among viewers.

- $\mathrm{H}_{2}$ : There is significant and positive influence of media planning of advertisement on political literacy.

- $\mathrm{H}_{3}$ : There is significant and positive impact of politically themed advertisement on political literacy among viewers.

- $\mathrm{H}_{4}$ : There is mediating role of media planning between politically themed advertisement and political literacy.

3.3 Sample Size: Krejcie and Morgan formula is used for sample determination and sample size revealed to be 384 at Margin of error-5\% and confidence level-95\% based on population of Delhi and National Capital Region (NCR).

3.4 Instruments: well design questionnaire is used for each study variable - Politically themed advertisement, media planning and political literacy with 10,6 and 10 items respectively.

3.5 Statistical Tools : SPSS 21 and Amos 21 are used for data analysis.

\section{DATA ANALYSIS AND INTERPRETATION}

4.1.Sample Description - it is important to describe the demographic profile of respondents before proceeding to descriptive and inferential analysis.

Table 4.1: Demographic Profile of the Respondents

\begin{tabular}{|c|c|c|c|c|}
\hline S. No. & Demographics & Dimensions & Frequencies & Percentage \\
\hline \multirow{2}{*}{1} & \multirow{2}{*}{ Gender } & Male & 212 & 55.2 \\
\hline & & Female & 172 & 44.8 \\
\hline \multirow{4}{*}{2} & \multirow{4}{*}{ Age } & $18-30$ & 273 & 71.1 \\
\hline & & $31-45$ & 67 & 17.4 \\
\hline & & $46-60$ & 38 & 9.9 \\
\hline & & 61 and Above & 6 & 1.6 \\
\hline \multirow{2}{*}{3} & \multirow{2}{*}{ Marital Status } & Single & 269 & 70.1 \\
\hline & & Married & 115 & 29.9 \\
\hline \multirow{3}{*}{4} & \multirow{3}{*}{ Education Qualification } & Undergraduate & 24 & 6.2 \\
\hline & & Graduate & 140 & 36.5 \\
\hline & & Post Graduate & 220 & 57.3 \\
\hline
\end{tabular}




\begin{tabular}{|c|l|l|c|c|}
\hline \multirow{2}{*}{5} & \multirow{3}{*}{ Profession } & Student & 230 & 59.9 \\
\cline { 3 - 4 } & & Salaried & 100 & 25.3 \\
\cline { 3 - 4 } & & Self-employed & 55 & 14.3 \\
\hline
\end{tabular}

Respondent profile result presented in table 4.1 revealed that 212 males and 172 females. Majority of respondents are in the age group of $18-30$ that is 273 followed by age group 31- 45 that is 67 . There are 269 respondents are single while 115 are married. There are 220postgraduates, 140 are graduate and 24 are undergraduate. Majority of respondents are students as 230 followed by salaried (100) and self-employed (55).

\subsection{Reliability Analysis}

Table 4.2: Reliability results

\begin{tabular}{|c|l|c|c|}
\hline S.N. & \multicolumn{1}{|c|}{ Variable } & No. of items & Cronbach Alpha \\
\hline 1 & Politically themed Advertisement & 10 & 0.828 \\
\hline 2 & Media Planning & 6 & 0.825 \\
\hline 3 & Political Literacy & 10 & 0.857 \\
\hline
\end{tabular}

Cronbach (1951) recommended that Cronbach alpha higher than 0.7 is considered as good scale with high internal consistency. Results of mentioned in table 4.2 revealed that scales for all variables used in present study are good scale with high internal consistency.

\subsection{Descriptive Analysis}

This is conducted to study the overall mean and standard deviation of sample with respect to variables taken under study.

Table 4.3: Descriptive Statistics of Variables

\begin{tabular}{|l|c|c|c|c|c|}
\hline \multicolumn{1}{|c|}{ Variables } & N & Minimum & Maximum & Mean & Std. Deviation \\
\hline Politically themed Advertisement & 384 & 1 & 5 & 3.338 & 0.643 \\
\hline Media Planning & 384 & 1 & 5 & 3.549 & 0.750 \\
\hline Political Literacy & 384 & 1 & 5 & 3.466 & 0.732 \\
\hline
\end{tabular}

The mean of all variables is reported more than average by respondents. The mean of Media Planning is reported highest that reveals that people are well aware of Media Planning and its role followed by political literacy. The lowest mean is reported for politically themed advertisement though it reveals that people are aware of politically themed advertisement.

\subsection{Regression Analysis}

Regression analysis had been conducted to examine some of the proposed hypotheses.

\subsubsection{Impact of politically themed advertisement on media planning}

In this regression analysis, politically themed advertisement is taken as independent variables and media planning is taken as dependent variable.

Table 4.4: Model summary of politically themed advertisement on media planning

\begin{tabular}{|c|c|c|c|c|}
\hline Model & R & R Square & Adjusted R Square & Std. Error of the Estimate \\
\hline 1 & $.654 \mathrm{a}$ & .428 & .427 & .56857 \\
\hline
\end{tabular}


a. Predictors: (Constant), Politically themed advertisement

The results of table 4.4 shows that the value of $\mathrm{R}=0.434$ indicates a moderate relationship between politically themed advertisementand media planning. The value of adjusted $\mathrm{R}^{2}=0.42 .7$ explains that $42.7 \%$ of the variation in media planning is explained by politically themed advertisement while $47.3 \%$ remain unexplained. Thus, the predictive ability of the model is moderate.

Table 4.5: ANOVA of politically themed advertisement on media planning

\begin{tabular}{|c|c|c|c|c|c|c|}
\hline Model & & Sum of Squares & df & Mean Square & F & Sig. \\
\hline 1 & Regression & 92.459 & 1 & 92.459 & 286.01 & $.000 \mathrm{~b}$ \\
\hline & Residual & 123.49 & 382 & 0.323 & & \\
\hline & Total & 215.949 & 383 & & & \\
\hline \\
b Predictors: (Constant), Politically themed advertisement \\
\hline
\end{tabular}

The ANOVA output table describes the overall variance accounted for in the model. The F value (286.01) and the significance value level (0.000) is less than 0.05 . Thus, there is significant impact of politically themed advertisement on media planning as is indicated by the f statistics.

Table 4.6: Standardized Coefficients of politically themed advertisement on media planning

\begin{tabular}{|c|c|c|c|c|c|c|}
\hline Model & & $\begin{array}{c}\text { Unstandardized } \\
\text { Coefficients }\end{array}$ & $\begin{array}{c}\text { Standardized } \\
\text { Coefficients }\end{array}$ & t & Sig. \\
\hline & & B & Std. Error & Beta & & \\
\hline 1 & (Constant) & 0.999 & 0.154 & & 6.507 & 0.000 \\
\hline & PBA & 0.764 & 0.045 & 0.654 & 16.912 & 0.000 \\
\hline \multicolumn{7}{|c|}{ a Dependent Variable: Media planning } \\
\hline
\end{tabular}

The standardized coefficient beta values indicated shown above indicates the change in politically themed advertisement has corresponding change in media planning. For example, from the table above, it is interpreted that unit change in politically themed advertisement has 0.654-unit change in media planning. This result leads to acceptance of proposed alternate hypothesis $\mathrm{H}_{1}$. It is interpreted that there is significant positive and impact of politically themed advertisement on media planning.

\subsubsection{Impact of Media Planning on political literacy}

In this regression analysis, media planning is taken as independent variables and political literacy is taken as dependent variable.

Table 4.7: Model Summary of Media Planning on political literacy

\begin{tabular}{|c|c|c|c|c|}
\hline Model & R & R Square & Adjusted R Square & Std. Error of the Estimate \\
\hline 1 & $.652 \mathrm{a}$ & .425 & .423 & .55647 \\
\hline \multicolumn{5}{|c|}{ a. Predictors: (Constant), Media planning } \\
\hline
\end{tabular}

In the table 4.7 shows that the value of $r=0.652$ indicates a moderate relationship between independent (role of media planning) and dependent (Political Literacy) variables of this study. The value of adjusted $r^{2}=0.423$ explains that $42.3 \%$ of the variation in political literacy is explained by role of Media Planning, while $47.7 \%$ remain unexplained. 
Thus, the predictive ability of the model is moderate.

Table 4.8: ANOVA of Media Planning on political literacy

\begin{tabular}{|c|c|c|c|c|c|c|}
\hline \multicolumn{2}{|c|}{ Model } & Sum of Squares & df & Mean Square & F & Sig. \\
\hline \multirow{2}{*}{1} & Regression & 87.386 & 1 & 87.386 & 282.200 & $\begin{array}{c}.000 \\
\text { b }\end{array}$ \\
\cline { 2 - 7 } & Residual & 118.290 & 382 & .310 & \\
\cline { 2 - 6 } & Total & 205.677 & 383 & & \\
\hline \multicolumn{7}{|c|}{ a. Dependent Variable: Political Literacy } \\
\hline \multicolumn{7}{|c|}{ b. Predictors: (Constant), Media Planning } \\
\hline
\end{tabular}

The Anova output table 4.8 describes the overall variance accounted for in the model. The $f$ value (282.2) and the small significance value level (0.000) indicate that Media Planning has an effect on Political Literacy as is indicated by the f statistics.

Table 4.9: Standardized Coefficients of Media Planning on political literacy

\begin{tabular}{|c|c|c|c|c|c|c|}
\hline \multirow{2}{*}{\multicolumn{2}{|c|}{ Model }} & \multicolumn{2}{|c|}{ Unstandardized Coefficients } & Standardized Coefficients & \multirow[t]{2}{*}{$\mathbf{t}$} & \multirow[t]{2}{*}{ Sig. } \\
\hline & & B & Std. Error & Beta & & \\
\hline \multirow[t]{2}{*}{1} & (Constant) & 1.208 & .137 & & 8.797 & .000 \\
\hline & MP & .636 & .038 & .652 & 16.799 & .000 \\
\hline
\end{tabular}

The result in the above table 4.9 shows that Media Planning is found significant positive and moderately related to Political Literacy. The standardized coefficient beta values indicated shown above indicates the change in Media Planning has a corresponding change in Political Literacy. It also confirms that Media Planning is having significant positive impact on Political Literacy. Thus, the alternate hypothesis $\mathbf{H}_{2}$ is accepted.

\subsubsection{Impact of Politically themed Advertisement on political literacy}

In this regression analysis, politically themed Advertisement is taken as independent variables and Political Literacy is taken as dependent variable.

Table 4.10: Model Summary of Politically themed Advertisement on political literacy

\begin{tabular}{|c|c|c|c|c|}
\hline Model & R & R Square & Adjusted R Square & Std. Error of the Estimate \\
\hline 1 & $.632 \mathrm{a}$ & .399 & .398 & .56881 \\
\hline \multicolumn{5}{|c|}{ a. Predictors: (Constant), Politically themed advertisement } \\
\hline
\end{tabular}

As the above table 4.10 shows, the value of $r=0.632$ indicates a moderate relationship between independent (Politically themed advertisement) and dependent (Political Literacy) variables of this study. The value of adjusted $\mathrm{r}^{2}=$ 0.398 explains that $39.8 \%$ of the variation in political literacy is explained by politically themed advertisement, while 60.2 $\%$ remain unexplained. Thus, the predictive ability of the model is moderate.

Table 4.11: ANOVA of Politically themed Advertisement on political literacy

\begin{tabular}{|l|l|l|l|l|c|}
\hline Model & Sum of Squares & df & Mean Square & F & Sig. \\
\hline
\end{tabular}




\begin{tabular}{|c|c|c|c|c|c|c|}
1 & Regression & 82.081 & 1 & 82.081 & 253.690 & $.000 \mathrm{~b}$ \\
\cline { 2 - 6 } & Residual & 123.596 & 382 & .324 & \\
\cline { 2 - 5 } & 205.677 & 383 & & \\
\hline Total & a. Dependent Variable: Political Literacy \\
\hline \multicolumn{3}{|c|}{ b. Predictors: (Constant), Politically themed advertisement } \\
\hline
\end{tabular}

The Anova output table 4.11 describes the overall variance accounted for in the model. The f value (253.690) and the small significance value level (0.000) indicate that Politically themed Advertisement has an effect on Political Literacy as is indicated by the f statistics.

Table 4.12: Standardized Coefficients of Politically themed Advertisement on political literacy

\begin{tabular}{|c|c|c|c|c|c|c|}
\hline \multirow{2}{*}{ Model } & \multicolumn{2}{|c|}{ Unstandardized Coefficients } & Standardized Coefficients & \multirow{2}{*}{ Sig. } \\
\cline { 2 - 7 } & B & Std. Error & Beta & \\
\hline \multirow{2}{*}{1} & (Constant) & 1.064 & .154 & & 6.922 & .000 \\
\cline { 2 - 7 } & PBA & .720 & .045 & .632 & 15.928 & .000 \\
\hline \multicolumn{7}{|c|}{ a. Dependent Variable: Political Literacy } \\
\hline
\end{tabular}

The results in the above table 4.12 show that Politically themed Advertisement is found significant positive and moderate relationship with Political Literacy. The standardized coefficient beta values indicated shown above indicates the change in Politically themed Advertisementhas corresponding change in Political Literacy. It also confirms that Politically themed Advertisement is having significant positive and moderate impact on Political Literacy. Thus, the alternate hypothesis $\mathrm{H}_{3}$ is accepted.

\subsection{Mediation Analysis}

The result of regression estimates between antecedents and consequences without mediator is presented in Table 4.13 and result of regression estimates between antecedents and consequences with mediator is presented in Table 4.14 followed by discussion.

Table 4.13: Regression Estimates of the Proposed Model (Without Mediator)

\begin{tabular}{|c|c|c|c|c|c|}
\hline Variable & Direction & Variable & Estimate & C.R. & P \\
\hline Political Literacy & $<--$ & $\begin{array}{c}\text { Politically themed } \\
\text { Advertisement }\end{array}$ & 0.632 & 11.999 & $* * *$ \\
\hline
\end{tabular}

The value of $\mathrm{p}$ and critical ratio in table 4.13 revealed that there is significant impact of Politically themed Advertisement on political literacy in direct relation.

Table 4.14: Regression Estimates of the Proposed Model (With Mediator)

\begin{tabular}{|c|c|c|c|c|c|}
\hline Variable & Direction & Variable & Estimate & C.R. & P \\
\hline $\begin{array}{c}\text { Role of Media } \\
\text { Planning }\end{array}$ & $<---$ & $\begin{array}{c}\text { Politically themed } \\
\text { Advertisement }\end{array}$ & 0.654 & 27.234 & $* * *$ \\
\hline Political Literacy & $<---$ & Role of Media Planning & .652 & 15.637 & $* * *$ \\
\hline Political Literacy & $<---$ & $\begin{array}{c}\text { Politically themed } \\
\text { Advertisement }\end{array}$ & .075 & 11.278 & .021 \\
\hline
\end{tabular}

The value of $\mathrm{p}$ and critical ratio in table 4.14 revealed that there is significant impact of input variables (Politically 
themed Advertisement) on outcome variable (political literacy) with mediator (Role of Media Planning). The relationship between Politically themed Advertisement and role of Media Planning; and relationship between role of Media Planning and Political Literacy are significant in indirect effect. The value of estimate between Politically themed Advertisement and political literacy is less in indirect effect as compared to direct effect. This confirms the partial mediation of role of Media Planning between Politically themed Advertisement and Political Literacy. Therefore, the alternate hypothesis $\mathbf{H}_{4}$ is accepted.

\section{CONCLUSIONS AND RECOMMENDATIONS}

The present study will highlight the role of television advertisement themed on political and democratic issues in creating political awareness in public. In the era of print media, political party and candidate had focus to reach to one to one voter apart from political rallies to reach to voters.

The results have revealed that there is positive and significant impact of politics-based advertisement of products on political literacy among viewers. In this study, politically themed advertisements are based political and democratic issues that creates interest and awareness among viewers about political and democratic system that influences voters in understanding political parties and their agenda as well as helpful in choosing right political party consciously and ultimately resulting in political participation. While, political literacy includes knowledge about advantages of democratic system, importance of democracy in society development, knowledge about right to vote, know the power of vote in nation building, analysis of each political party before casting your vote, literate about government policy and agenda, awareness about politicalissues and events, knowledge about EVM and or ballot paper, knowledge about different forms of vote like by post or by proxy, and knowledge about polling station functioning and opening hours. It is concluded that by enhancing the level of political and democratic issue themed advertisement is improving awareness in viewers about political literacy.

The second objective of this study is to find the impact of media planning of advertisement on political literacy. The results have revealed that there is positive and significant impact of media planning on political literacy. In this study, media planning refers to creativity of the advertisement, placement of advertisement, duration of advertisement, visual appearance, audio support and repetition of advertisement better effectiveness and developing positive attitude. It is concluded that media planning is important in improving political literacy among viewers. The next objective of this study is to find the influence of politics-based advertisement of products on media planning. The results confirmed that there is significant and positive influence of politics-based advertisement of products on media planning. It is concluding that there is close relationship between politics-based advertisement and media planning. The last objective of this study is to examine the mediating role of media planning between politically themed advertisement and political literacy.Based on results it is concluded that media planning is mediating the role between politically themed advertisement and political literacy. It concluded that the role of television advertising in changing political perceptions of voters, their understanding of the electoral process and political philosophy of different political parties.

It is recommended that leading brands can adopt different issues of politics and democratic system in advertisement for better participation of voters. Government, NGO and other associated agencies should promote such relevant commercials in future aimed at improving voter's participation and turnout in electoral process through other means of mass communication.

\subsection{Limitations and Future Scope}


This study is limited to 384 respondents of Delhi-NCR. This study is focused on 3 study variables -politically themed advertisement,media planning and political literacy. In future scope, it is suggested to include more respondents from different geographical locations of the country with more topical variables.

\section{REFERENCES}

4 Arora, Shruti, and Anukrati Sharma. "Social media: a successful tool of brand awareness." International Journal of Business and General Management (IJBGM) 2.3 (2013): 1-14.

5 Baggett, P.\& Ehrenfeucht, A. (1983). Encoding and retaining information in the visuals and verbal of an educational movie. Educational Communication and Technology Journal, 31(1), 23-32.

6 Beagles-Roos, J. \& Gat, I. (1983). Specific impact of radio and television on children's story comprehension. Journal of Educational Psychology, 75(1), 128-137.

7 SREEKALA, G. "TECHNOLOGY'S ROLE IN COMMODIFICATION OF NOT-FOR-PROFIT MEDIA. "International Journal of Research in Humanities, Arts and Literature (IMPACT: IJRHAL) ISSN (P): 2347-4564; ISSN (E): 2321-8878International Journal of Communication and Media Studies (IJCMS) 7,.4, Oct 2017, 53-60.

8 Calvert, S. L., Huston, A. C., Watkins, B. A., \& Wright, J. C. (1982). The relation between selective attention to television forms and children's comprehension of content. Child Development, 53 (1), $601-610$.

9 Cronbach, L. J. (1951). Coefficient alpha and the internal structure of tests. Psychometrika, 16(3), pp. 297-334.

10 Drew, D. G. \& Grimes, T. (1987). Audio-visual redundancy and TV news recall. Communication Research, 14 (4), $452-461$.

11 GAURAV SINGH, N. I. T. Y. "ROLE AND IMPACT OF MEDIA ON SOCIETY: A SOCIOLOGICAL APPROACH WITH RESPECT TO DEMONETISATION." International Journal of Research in Humanities, Arts and Literature (IMPACT: IJRHAL)

12 Hanson, L. (1989). Multichannel learning research applied to principles of television production: Review and synthesis of the literature. Educational Technology, 29(10), 15-19.

13 Hayes, D. S., Kelly, S. B., \& Mandel, M. (1986). Media differences in children's story synopses: Radio and television contrasted. Journal of Educational Psychology, 78(5), 341-346.

14 Kaur, H. \& Kaur, R. (2002). Fashion Awareness among Rural and Urban Adolescents. Journal of Social Research, 43(1): $37-$ 40.

15 Kozma, R. (1994). Will media influence learning: Reframing the debate? Educational Technology Research and Development, 42(2), 7-19.

16 Setyanto, Y. U. G. I. H., S. E. P. T. I. A. Winduwati, and LUSIA SAVITRI SETYO Utami. "Early Adolescent Behavior on Media Toward Idol Figure (Parasoial Study Preliminary Youth As An Effect of New Media)." International Journal of Communication and Media Studies (IJCMS) Vol 7 (2017).

17 Krejcie, R.V., \& Morgan, D.W., (1970). Determining Sample Size for Research Activities. Educational and Psychological Measurement. Retrieved from : http://www.kenpro.org/sample-size-determination-using-krejcie-and-morgan-table/

18 Laurillard, D. (1991). Mediating the message: Programme design and students' understanding. Milton Keynes, Great Britain: Open University, Programme on Learner Use of Media, Paper No. 3.

19 Menon, R. (2013, December 24). Vicks Cough drops: Pitch Perfect. Retrieved from http://www.afaqs.com/news/story/39524_Vicks-Coughdrops:-Pitch-Perfect. 
20 Miller, G. A. (1956). The magical number seven plus or minus two: Some limits of our capacity for processing information. Psychological Review, 63(2), 81-97.

21 MTV launches _Rock the Vote' initiative aimed at the youth. (2013, December 9). Retrieved from http://www.bestmediainfo.com/2013/12/mtv-launches-rock-the-vote-initiative-aimed-at-the-youth.

22 Nagpal, P. A. (2013, May 28). ABP News promises its informed viewers an audience. Retrieved from http://www.campaignindia.in/Video/344799,abp-news-promises-its-informed-viewers-an-audience.aspx.

23 Neuman, S. B. (1989). The impact of different media on children's story comprehension. Reading Research and Instruction, $28(4), 38-47$

24 New Rupa Frontline ad promotes voting. (2013, January 17). Retrieved from http://bmi.mediology.in/2013/01/new-rupafrontline-ad-promotes-voting.

25 Now brands piggyback elections. (2014, April 19). Retrieved from http://www.indiantelevision.com/mam/mediaandadvertising/ad-campaigns/now-brands-piggyback-elections-140419.

26 Sen, S. (2014, March 28). Google salutes democracy with Independent India 's first-ever voter. Retrieved from http://www.bestmediainfo.com/2014/03/google-salutes-democracy-with-independent-indias-first-ever-voter.

27 Sen, S. (2014, May 6). Short is powerful as Wagon $R$ goes for a 10-seconder. Retrieved from http://www.bestmediainfo.com/2014/05/short-is-powerful-as-wagonr-goes-for-a-10-seconder/.

28 Shashidhar, A. (2014, April 7). Election pitch: Google urges Indians to vote with true life story Retrieved from http://businesstoday.intoday.in/story/google-urges-indians-to-vote-lok-sabha-election-ad-campaign/1/204700.html.

29 Srinivasan, L. (2014, April 3). HUL latest to take poll position with TV campaign Retrieved from http://www.financialexpress.com/news/hul-latest-to-take-poll-position-with-tv-campaign/1237875.

30 Srivastava, P. (2014). Tata Tea encourages 'Kala Teeka' for women. Retrieved from http://www.afaqs.com/news/story/40027_Tata-Tea-encourages-\%27Kala-Teeka\%27-for-women.

31 STAR Plus Veera campaign encourages first time voters to make a difference. (2014, February 1). Retrieved from http://www.indiantelevision.com/television/tv-channels/gecs/star-plus-veera-campaign-encourages-first-timevoters-to-make-adifference-140201.

32 Shivraj, P., and H. Philip."Role of mass media in changing awareness level on climate change among small and marginal paddy farmers of Tamil Nadu." Int J Humanities and SocSci Interventions 5.4 (2016): 45-50.

33 Katz, Yaron. "Social Media Is Powerful, but Can It Change Policies of Institutionalized Organizations Such as the Israeli Army?." International Journal of Humanities and Social Sciences (IJHSS) 6.6 (2017): 29-34.

34 Thorson, E., Reeves, B., \&Schleuder, J. (1985). Message complexity and attention to television. Communication Research, $12(4), 427-454$. 

